\title{
Protective Effect of Ginger Extract against Contrast media-Induced Nephrotoxicity in
} Rats.

\author{
Mohammed H. Sheriff ${ }^{1}$, Al-shimaa M. Abas ${ }^{2}$ and Lobna A. Zaitoun ${ }^{2}$ \\ ${ }^{1}$ Chemistry Department, Faculty of Science, Zagazig University, Egypt \\ ${ }^{2}$ Biochemistry Division, Chemistry Department, Faculty of Science, Zagazig University, Egypt
}

\begin{tabular}{l}
\hline A R T I C L E I N F O \\
\hline Article history: \\
Received : \\
Accepted : \\
Available online : \\
Keywords: \\
Nephrotoxicity, Ginger extract, \\
Urografin, Cystain C, NGAL and \\
$T N F \alpha$
\end{tabular}
$T N F \alpha$ \begin{abstract}
A B S T RA C T
Background: Nephrotoxicity was reported in the initial clinical trials of contrast media. Aim of study: Our study was designed to evaluate the protective effect of ginger extract against nephrotoxicity induced by contrast agent. Material \& Methods: Animals were divided into 5 groups as follow: Group1 (Control): They were not received any treatment during experiment period. Group2 (Ginger): Animals were deprived from water for 72 hours , then orally administrated with $400 \mathrm{mg} / \mathrm{Kg} /$ day of ginger extract for 72 hours. Group3 (protective): Animals were pre administrated orally with ginger extract with $400 \mathrm{mg} / \mathrm{Kg}$ for one week, then rats were deprived of water for 72 hours, then urografin was induced by a single (I.V.) at dose of $10 \mathrm{~mL}$ per $\mathrm{kg}$ after that animals were orally administrated with $400 \mathrm{mg} / \mathrm{Kg}$ /day of ginger extract for 3 consecutive days. Group 4 (positive)(contrast media): Animals were induced by a single intravenous (I.V.) of urografin at dose of $10 \mathrm{~mL}$ per $\mathrm{kg}$ after deprivation of water for 72 hours. Group 5(therapeutic): Animals rats were deprived of water for 72 hours, then Contrast-induced nephrotoxicity was induced (as group 4) , after that animals were post administrated with ginger extract $400 \mathrm{mg} / \mathrm{Kg}$ (for 3 days). Results: Administration contrast media caused significant elevation in serum urea, creatinine concentration, kidney tissue levels of MDA and NO. Also it caused significant increase in Cystain $\mathrm{C}$, NGAL and TNF $\alpha$ levels. Also it significantly decreased SOD activity and GSH level. Treatment with Ginger extract restored the elevation of concentration of urea and creatinine, also oxidative stress markers in groups 3 and 5 and decreased Cystain C, NGAL and TNF $\boldsymbol{\alpha}$ levels. Histopathological analysis confirmed that. Conclusion: ginger extract have a protective role in contrast media induced nephrotoxicity. C 2018 Publisher All rights reserved.
\end{abstract}

\section{INTRODUCTION}

Contrast-induced nephrotoxicity (CIN) is a vital complication resulting from interventional therapy and diagnostic radiographic imaging. It follows administration of intravascular iodinated contrast media $(\mathrm{CM})$ and the third most common cause of hospital-acquired acute kidney failure at present. CIN is correlated with increased morbidity, prolonged hospitalization, and higher mortality ${ }^{(1)}$. 
The pathophysiology of contrast media induced nephrotoxicity depends on three separate but interacting mechanisms: reactive oxygen species (ROS) formation, toxicity of direct tubular cell and medullary ischemia ${ }^{(2)}$. The nephrotoxicity of contrast media is shown by an elevation in serum creatinine level ${ }^{(3)}$.

Iodinated contrast media (iodinated CM) have elevated the ability of absorbing $\mathrm{x}$ rays and visualizing structures that normally are difficult to detect in a radiological examination. The utilization of iodinated contrast media may destroy renal function, commonly known as contrast-induced nephropathy (CIN), which can cause acute renal failure $(\mathrm{ARF})^{(4)}$. Diatrizoate (Urografin) induces kidney injury through a combination of direct toxic effect and renal ischemia on renal tubular cells ${ }^{(5)}$. Diatrizoate exposure leads to excess production of oxygen free radicals and decrease of antioxidant enzyme activity in the rat kidney kidney ${ }^{(6)}$.

Ginger (Zingiber officinale), a member of the Zingiberaceae family, is a spice utilized in the daily diet in many Asian countries $^{(7)}$. It was showed that ginger also possessed anti-cancer, anticlotting, antiinflammatory, and analgesic activities ${ }^{(8)}$. Extracts of the ginger are rich in shagaols and gingerols which exhibit antiinflammatory, anti-oxidant and anticarcinogenic proprieties under "in vitro" and "in vivo"systems ${ }^{(9)}$.

\section{Materials and Methods.}

\section{Material :}

Urografin: was purchased from Bayer Co.( New Zealand ).

Each $\mathrm{mL}$ provides $660 \mathrm{mg}$ diatrizoate meglumine and $100 \mathrm{mg}$ diatrizoate sodium.

Iodine concentration $(\mathrm{mg} / \mathrm{ml}): 370$

Osmolality (osm/kg H2O) : 2.10

\section{Animal management}

Adult female albino rats, weighing 205.0 $\pm 12.9 \mathrm{~g}$, were obtained from the
Experimental Animal Care Center in Cairo and were housed in metabolic cages under controlled environmental conditions $\left(25^{\circ} \mathrm{C}\right.$ and a $12 \mathrm{~h}$ light/dark cycle) one week before starting the experiment as acclimatization period. The animals were fed with libtium and provided with drinking water.

\section{Ginger extration}

The $Z$. officinale rhizome (ginger) was obtained from local commercial sources in Egypt. The plant material was dried at oven before being pulverized with an electric grinder. The powdered ginger was extracted with ethanol utilizing Soxhlet apparatus for $48 \mathrm{~h}$. The extract was concentrated to dryness with rotary evaporator to yield ethanolic ginger extract $(\mathrm{EGE})^{(10)}$

\section{Experimental design :}

After the acclimatization period, a total of 50 adult female albino rats were divided into five groups with 10 animals in each group.

Group 1(control): They were not received any treatment during experiment period.

Group 2 (ginger extract): After the acclimatization period, Rats were not received any treatment during the first week of experiment. Rats were deprived of water for 72 hours, and then ginger was administrated orally to the rats at a dose of $400 \mathrm{mg} / \mathrm{kg}$ once daily for 3 consecutive days.

Group 3 (protective): After the acclimatization period, Rats were pre administrated orally with ginger extract at dose $400 \mathrm{mg} / \mathrm{kg}$ for one week, then rats were deprived of water for 72 hours, on the day 11 , they received urografin at dose of $10 \mathrm{ml} / \mathrm{kg}$ by a single (I.V.) . After that rats post administrated orally with ginger extract at dose $400 \mathrm{mg} / \mathrm{kg}$ for 3 days.

Group 4 (positive) (contrast media): After the acclimatization period, Rats were not received any treatment during the first week of experiment. Then rats were deprived of water for 72 hours. After that 
contrast-induced nephrotoxicity was induced by a single intravenous (I.V.) of high-osmolar contrast media diatrizoate (Urografin $76 \%$ ) at dose of $10 \mathrm{~mL}$ per $\mathrm{kg}$, into the tail vein under ether anesthesia at day 11.

Group 5 (Therapeutic): After the acclimatization period, Rats were not received any treatment during the first week of experiment. Then rats were deprived of water for 72 hours. Contrastinduced nephrotoxicity was induced (as group 4) by a single (I.V.) of urografin, then animals were post administrated with ginger extract at dose $400 \mathrm{mg} / \mathrm{kg}$ (for 3 days).

\section{Collection and sampling of blood:}

At the end of experimental period (14 day), the animals were fasted for 12 hours, anesthetized with ether, then a capillary tube was inserted into the medial canthus of the eye (30 degree angle to the nose). The serum was prepared by collection of blood in anticoagulant -free tube, then left for 10minutes in water bath at 37 until clot, then centrifuged at 2000 rpm for 10 minutes for separation of serum which was transferred into eppendorff tubes and kept frozen at -20 until analysis

\section{Tissue processing for oxidative,} inflammatory parameters and histopathological examination

\section{Estimation of Biochemical Studies}

Estimation of serum urea and creatinine were performed by colorimetric method according to ${ }^{(11),(12)}$ respectively.

Level of kidney tissue homogenate NO, MDA, GSH and SOD activity were determined according to ${ }^{(13),(14),(15),(16)}$ using colorimetric kit purchased from Biodiagnostic Company (Biodiagnostic, Egypt) respectively.

Rat Cystain C, Neutrophil Gelatinase Associated Lipocalin (NGAL) and Tumor Necrosis Factor $\alpha$ (TNF- $\alpha)$ parameters were determined by ELISA according to Catalogue No. CSB-E08385r, E-ELR0714 and 201-11-0765 kits respectively.

\section{Statistical Analysis}

All results were analyzed by SPSS software (version 14). Data were expressed as mean \pm SD. Comparison of mean values of studied variables among different groups was done using ANOVA test. $\mathrm{P}<0.05$ was considered to be significant ${ }^{(17)}$.

\section{RESULTS}

\section{Effect of deprivation of water on body weight.}

Results presented in table (1), figure(1) showed that weight loss of approximately $10: 15 \%$ occurred after a $72 \mathrm{~h}$ interval of water deprivation in all groups.

After blood collection kidney was removed, rinsed with ice-cold phosphate-buffered salineKidney function tests in all studied ( $\mathrm{pH}$ 7.4). The homogenates were centrifuged andgroups.

the supernatants obtained were transferred intoContrast media caused significant increase eppendorf tubes for lipid peroxidation (MDA), in serum urea and creatinine levels ( $\mathrm{P}<$ nitric oxide levels, super oxide dismutase,0.05). Administration of ginger extract glutathione, cystain C, Neutrophil Gelatinasebefore and along with contrast agent Associated Lipocalin and tumor necrosis factor $\alpha$ reduced the elevation in their levels concentration. Another part of kidney was fixed incompared to contrast media group $10 \%$ buffered formalin for histopathological $(\mathrm{P}>0.05)$ (Table2), (Figures2\&3). examination. Three $\mu \mathrm{m}$-thick paraffin sections were stained with hematoxylin and eosin $(\mathrm{H}$ and Effect of ginger extracts on oxidative E) for light microscope examination usingstress markers and antioxidant levels. conventional protocol. Histopathological studiesResults presented in table(3) showed that were performed under a light microscope. 
control group, this value showed statistically non-significant elevation in ginger group $(17.1 \pm 1.94 \mu \mathrm{mol} / \mathrm{L})$ and protective group $(20.72 \pm 1.3 \mu \mathrm{mol} / \mathrm{L})$ which amounted to 3.2 and $25.05 \%$ respectively (P>0.05). While the mean level of NO concentration showed significant increase in therapeutic group $(23.82 \pm 1.51 \mu \mathrm{mol} / \mathrm{L})$ $(\mathrm{P}<0.05)$ and positive group (contrast media) $\quad(28.34 \pm 4.1 \mu \quad \mathrm{mol} / \mathrm{L}) \quad(\mathrm{P}<0.0001)$ which amounted to 43.75 and $71.03 \%$ respectively compared to control group Figrue(4).

Also the mean level of MDA concentration was found to be $(10.55 \pm .96$ $\mathrm{nmol} / \mathrm{g}$ ) in control group, this value showed statistically non-significant decrease in ginger group (9.85 4.572 $\mathrm{nmol} / \mathrm{g}$ ) which amounted to $6.64 \%$ $(\mathrm{P}>0.05)$. While the mean level of $\mathrm{NO}$ concentration showed significant increase in therapeutic group $(13.59 \pm 1.2 \mathrm{n} \mathrm{mol} / \mathrm{g})$ $(\mathrm{P}<0.05)$ and positive group (contrast media) $(15.84 \pm 1.55 \mathrm{nmol} / \mathrm{g}) \quad(\mathrm{P}<0.0001)$ which amounted to 28.81 and $50.14 \%$ respectively and non-significant increase in protective group $(12.36 \pm .97 \mathrm{nmol} / \mathrm{g})$ which amounted to $17.16 \%$ ( $\mathrm{P}>0.05)$ compared to control group Figrue(5).

The mean value of GSH level was found to be $(1.19 \pm .108 \mathrm{mg} / \mathrm{g})$ in control group, this value showed statistically nonsignificant increase in ginger group $(1.25 \pm .128 \mathrm{mg} / \mathrm{g})$ which amounted to $5.04 \%(\mathrm{P}>0.05)$. While the mean value of GSH level showed significant decrease in therapeutic group $(.81 \pm .18 \mathrm{mg} / \mathrm{g})(\mathrm{P}<0.05)$ and positive group (contrast media) $(.48 \pm .18 \quad \mathrm{mg} / \mathrm{g}) \quad(\mathrm{P}<0.0001) \quad$ which amounted to 31.93 and $59.66 \%$ respectively and non-significant decrease in protective group $(.97 \pm .128 \mathrm{mg} / \mathrm{g})$ which amounted to $18.49 \%(\mathrm{P}>0.05)$ compared to control group Figrue(6).

The mean value of SOD activity was found to be $(19.02 \pm 1.16 \mathrm{U} / \mathrm{g})$ in control group, this value showed statistically nonsignificant decrease in ginger group $(18.8 \pm .64 \mathrm{U} / \mathrm{g})$ and protective group $(16.26 \pm .98 \mathrm{U} / \mathrm{g})$ which amounted to 1.16 and $14.51 \%$ respectively $(\mathrm{P}>0.05)$. While the mean level of SOD activity showed significant decrease in therapeutic group $(13.06 \pm 2.47 \mathrm{U} / \mathrm{g})$ and positive group (contrast media) $(.48 \pm 1.8 \mathrm{U} / \mathrm{g})(\mathrm{P}<0.0001)$ which amounted to 31.33 and $43.43 \%$ respectively compared to control group Figrue(7).

\section{Effect of ginger extract on Cys- C, NGAL and TNF- $\alpha$ markers.}

The mean levels of Cys- C , NGAL and TNF- $\alpha$ showed statistically non-significant increase in ginger only treated group compared to control group ( $p>0.05)$.

In group 4 positive group (contrast media) administration of contrast media caused significant elevation in Cys- C, NGAL and TNF- $\alpha$ levels in kidney tissue compared to control group $(p<0.0001)$. Treatment with ginger extract before and along with contrast media significantly reduced the elevation in Cys- C , N-GAL and TNF- $\alpha$ level in group 3 (protective) $(\mathrm{P}<0.05)$, while showed non-significant decrease in group 5 (therapeutic) $(\mathrm{P}>0.05)$ compared to contrast media group .(Table4), (Figure8,9\&10).

\section{Histopathological examination of kidney tissue}

Histological examinations of tissue sections from the kidney showed vacuolated glomeruli and degenerated of some renal tubules with luminal renal cast were observed in the group 4 (positive) (contrast media). While in group 5(therapeutic) showed regenerative changes in the renal tubules and in group 3 (protective) the kidney tissues were protected against contrast media-induced damage and showed normal glomeruli and renal tubules with no pathological changes when compared with the control kidney tissue slide (Figure 11).

\section{DISCUSSION}

Many models of experiment have been helped in the studies of contrast media induced nephrotoxicity ${ }^{(18),(19)}$. It has been 
reported that dehydration potentiates the contrast media vasoconstrictive effects ${ }^{(20)}$ . Also, the high-dose and high-osmolarionic contrast media use, such as diatrizoate, are important risk factors for developing CIN (21) · Therefore, a prolonged dehydration period was used before the administration of high-dose diatrizoate. Severe medullary congestion, severe protein cast and moderate tubular necrosis were predicted.

Our results showed that all rats of all groups lost approximately 10:15\% of their baseline body weight after 3 days of dehydration period (Table1). These results are in agreement with (22). Also (23) reported that After 3 days of dehydration, in all groups, water intake was increased almost 2.5-fold; all rats developed anuria, and they lost approximately $15 \%$ of their baseline body weight.

It is considered that Serum creatinine and urea levels were considered the main parameters that determine kidney functions ${ }^{(24)}$. The elevation in the serum levels of these renal biomarkers might be cause of the impaired renal functions, tubular obstruction, and/or the backleakage of the renal tubules ${ }^{(25)}$.

Renal function can also be determined by analyzing the serum urea level. During the metabolism of protein in the body, the liver produces ammonia which is transformed into a byproduct called urea. However, due to renal dysfunction, urea is released into the bloodstream as serum urea. Therefore, higher serum urea level is directly proportional to harshness of renal damage ${ }^{(26)}$.

Our results showed that the mean level of urea concentration showed to be statistically non-significant increase $(\mathrm{P}>0.05)$ and slight decrease in creatinine concentration $(\mathrm{P}>0.05)$ in ginger group which amounted to 1.5 and $2.39 \%$ respectively compared to control group.

In positive (contrast media) group the mean level of urea and creatinine concentration $(\mathrm{P}<0.05)$ showed significant increase which amounted to
10.92 and $22.62 \%$ respectively compared to control group which indicate impairment of kidney function (Table 2 ) . The elevation in the serum levels of these renal biomarkers might be due to contrast agents reduce renal function through a combination of renal vasoconstriction with consequent hypoxia, and direct toxicity on tubular epithelial cells ${ }^{(27),(28)}$.

These results are in line with ${ }^{(29),(30)}$ who stated that contrast media nephrotoxicity occurs after intravascular administration of iodinated radiographic contrast medium. An increase in urea and creatinine concentrations correlates to contrast media nephrotoxicity.

Also our results of kidney functions levels were found to be elevated by contrast media in agreement with findings of (31) who reported that contrast media-induced nephrotoxicity was evident by increase in serum urea and creatinine levels in the rats.

Treatment with ginger in both preventive and therapeutic groups non significantly reduced the elevation in urea and creatinine concentration which amounted to 7.79 and $16.51 \%$ respectively in protective group and 3.16 and $10 \%$ respectively in therapeutic group compared to positive group $(\mathrm{P}>0.05)$ suggesting that ginger possess a preventive more than a curative property against contrast media nephrotoxicity. Our results in agreement with ${ }^{(32)}$ who revealed that treatment with ginger extract ameliorated kidney function parameters ( creatinine and urea ) and ${ }^{(33)}$ who stated that the combination treatment (both chromate and ginger) could partially protect the elevation of serum urea, uric acid and creatinine. Thus showing the ability of ginger extract to protect against chromate induced kidney damage.

Oxidative stress increase is one of the main underlying mechanisms in pathogenesis of contrast induced nephrotocity $^{(34)}$. Impairment in the antioxidant defense mechanism also has been revealed, including increased lipid 
peroxidation and inactivated antioxidant enzyme ${ }^{(35),(36)}$.The mechanisms of cellular antioxidant defense consist of enzymatic antioxidant components such as glutathione peroxidase and superoxide dismutase, catalase and of non-enzymatic antioxidant components such as vitamin $\mathrm{E}$, vitamin $\mathrm{C}$ and glutathione.

Research in the field of pathophysiology of CIN suggests that this condition is caused by oxidative injury, renal ischaemia and direct tubular epithelial cells toxicity ${ }^{(37)}$. After contrast media administration, reactive oxygen species cause lipid peroxidation and cytotoxic damage, suggesting that oxidative injury is a main factor in the CIN pathogenesis. After the injection of contrast media, free radicals react with nitric oxide producing peroxynitrite, an oxidative and very reactive nitrosative species capable of decreasing the bioavailability of nitric oxide, thereby increasing tissue damage .This reactive species utilizes its oxidative effects on the sulphydrylic groups and aromatic rings of proteins, cellular membrane lipids and nucleic acids ${ }^{(38)}$.

Our results found that the mean level of NO concentration showed statistically non significant elevation and statistically non significant decrease in MDA level in ginger group which amounted to 3.2 and $6.64 \%$ compared to control group (P > $0.05)$.

In positive (contrast media) group the mean level of NO and MDA concentrations showed statistically significant elevation which amounted to 71.03 and $50.14 \%$ respectively compared to control group $(\mathrm{P}<0.001)$. While the mean level of GSH and SOD activity showed significant decrease which amounted to 59.66 and $43.43 \%$ respectively compared to control group $(\mathrm{P}<0.001)$ (Table3). These data are in agreement with (29),(39) who indicated iodine-containing contrast agents can provide iodine atoms, which are directly involved in the generation of oxygen radicals .
Also our results are in line with ${ }^{(40)}$ who reported increased MDA level and decreased SOD activity in serum and renal tissues exposed to $\mathrm{CM}$ suggests that they were consumed due to increased oxidative stress. Moreover, the elevated MDA and reduced SOD in rat plasma that exposed to $\mathrm{CM}$ reflect an increase in lipid peroxidation and decrease antioxidation in the systemic response.

NO can give rise to lipid peroxidation resulting in the formation of reactive nitrogen products in excessive quantities. It can directly lead to DNA damage, mitochondrial membrane damage, or apoptosis through the p53 tumor suppressor gene stabilization pathway and damage in intracellular proteins and enzymes ${ }^{(41),(42)}$. A rise in NO can lead to apoptotic or necrotic injury in tubular epithelial cells ${ }^{(43)}$.

Our results are in line with ${ }^{(44)}$ who declaired that CIN significantly increased denudation of tubular cells and intratubular obstruction by granular casts following increased MDA and total NO levels.

Also our results are in line with ${ }^{(45)}$ who reported that contrast media reduced SOD and GSH levels compared to control group.

(46) reported a reduction in $(\mathrm{GSH})$ and (SOD) activities in rat kidney after contrast media treatment which may be due to free radicals generation as a reaction to contrast agent (diatrizoate). This proliferation damages red blood cells (RBCs) and organ tissues, primarily renal also. One possible explanation for the observed activities of these biochemical markers can be attached to induction, where free radicals are converted into less harmful or harmless metabolites. Another explanation is that diatrizoate promotes direct stimulatory or inhibitory pathways of the activity. For example, GSH controls redox status as a reducing agent or a major antioxidant within the cells.

Our results revealed that in protective group, ginger caused significant reduced the elevation in the mean NO and MDA 
levels which amounted to 26.86 and 21.97 $\%$ compared to positive (contrast media) group $(\mathrm{P}<0.0001)$ and increase the level of GSH and SOD activity which amounted to 102 and $51.11 \%$ compared to positive (contrast media) group ( $\mathrm{P}<0.0001)$.

Our results showed that in therapeutic group, the mean level of NO and MDA showed reduced elevation which amounted to 15.95 and $14.21 \%$ respectively ( $\mathrm{P}$ $<0.05)$ and $(\mathrm{P}>0.05 \quad)$ respectively compared to positive (contrast media) group. The mean value of GSH level and SOD activity showed increase which amounted to 68.75 and $21.38 \%$ respectively $(\mathrm{P}<0.0001)$ and $(\mathrm{P}>0.05)$ respectively compared to positive (contrast media) group.

These results agreed with ${ }^{(47)}$ who suggest that its inhibitory effect is similar to that attributed to [6]-gingerol, as it inhibited production of NO in lipopolysaccharide (LPS)-activated macrophages and reduced iNOS protein levels in these cells ${ }^{(48)}$.

(49) reported that young rhizome of $\mathrm{Z}$. officinale had higher content of flavonoids and high antioxidant activity. Results of this study described that, ginger extract ameliorated metalaxyl induced nephrotoxicity. This effect is mediated by either its direct free radicals scavenging activity or by preventing metalaxylinduced decline of renal antioxidant defense system.

Also our results are in line with ${ }^{(50)}$ who reported that level of GSH and SOD activity were elevated in rats dosed with ginger extract alone and also in ginger plus alcohol treated rats. This increase may be due to the presence of antioxidant bioactive compounds in ginger. The antioxidant compounds, like gingerols, shogals, ketone compounds and the phenolic compounds of ginger were responsible for scavenging the superoxide anion radicals.

Moreover it was observed that ginger significantly decreased levels of $\mathrm{NO}$ and MDA $(\mathrm{P}<.0001)$. This is in agreement with (51) who reported that administration of ginger extract cause increased level of catalase while decreased levels MDA and NO.

In addition, ginger treatment significantly restored GSH and SOD level $(\mathrm{P}<.0001)$ in line with ${ }^{(32)}$ who reported that, high levels of flavonoid and polyphenolic compounds with high antioxidant activity for ginger. The presence of flavonoids and polyphenols in the ginger extract might be responsible for the antioxidant and nephroprotective activities.

Cys-C (a 13 kDa) a non-glycosylated protein that is a cysteine protease inhibitor which is produced in all nucleated cells, cystatin $\mathrm{C}$ belongs to the subgroup of cysteine proteases. Its concentration in blood remains a more sensitive biomarker of AKI than $\mathrm{SCr}^{(52)}$.

It is filtered by glomeruli and then metabolized in proximal renal tubule cells following Megalin-mediated endocytosis (53). Unlike creatinine, Cys-C is not secreted in the urine by renal tubules.

Our results found that the mean level of cystain c showed statistically non significant elevation in ginger group which amounted to $2.45 \%$ compared to control group $(\mathrm{P}>0.05)$.

Our results demonstrated that treatment with contrast media in positive (contrast media) group showed significant increase on the mean level of cystain $c$ which amounted to $104.59 \% \quad(\mathrm{P}<0.001)$ compared to control group.

This finding was in agreement with those obtained by ${ }^{(54),(55)}$ reported the potential association between the increase of Cys $\mathrm{C}$ and the occurrence of CIN. A certain rise of the concentration of Cys $\mathrm{C}$ is sensitive and specific for the prediction of CIN after contrast medium exposure .

Meta-analysis indicates the high predictive power of serum cystatin $C$ assessed within $24 \mathrm{~h}$ after renal injury for all-cause AKI (56). This was supported for the contrastinduced nephrotoxicity in the largest study so far by Briguori et al. ${ }^{(57)}$.

When acute kidney injury occurs, the decreased GFR will cause an increase in serum Cys-C, taking place much earlier 
than the increase in serum creatinine. In contrast media induced acute kidney failure, serum Cystain $\mathrm{C}$ has been revealed to peak as early as 24 hours after radiocontrast administration, thereby allowing detection of even small changes in GFR. ${ }^{(\mathbf{5 8}),}{ }^{(59),(60)}$. (61) concluded that serum Cys-C is a useful marker of AKI and may detect AKI 1-2 days earlier than serum creatinine.

Human NGAL, a member of the lipocalin superfamily, was initially defined as a 25$\mathrm{kDa}$ protein which bound covalently to gelatinase in neutrophils and appeared at low concentrations in, stomach, colon trachea, lungs and normal kidney ${ }^{(62)}$. NGAL is filtered by glomeruli and then reabsorbed by proximal tubules where it is partly degraded by megalin and partly excreted in the urine. Following renal tubular cell damage, NGAL is released into the plasma and the urine; this causes a rise in its plasma and urine concentration, much earlier than the increase in serum concentration of creatinine ${ }^{(63)}$.

Our results found that the mean level of NGAL showed statistically non-significant elevation in ginger group which amounted to $4.88 \%$ compared to control group (P > $0.05)$.

Our results demonstrated that treatment with contrast media in positive (contrast media) group showed significant increase on the mean level of NGAL which amounted to $31.5 \%(\mathrm{P}<0.001)$ compared to control group ( Table4 ) that was in harmony with ${ }^{(64)}$ who stated that Neutrophil Gelatinase-Associated Lipocalin as an Early Marker of ContrastInduced Nephrotoxicity After Elective Invasive Cardiac Procedures.

The inflammatory process is factor occurring in the pathogenesis of nephrotoxicity. In this process, macrophages released because of inflammation increase the production of proinflammatory cytokines in addition to oxidant release ${ }^{65),(66)}$. Previous studies revealed that contrast media administration led to increased levels of proinflammatory cytokines in the kidneys. Although increasing TNF- $\alpha$ is also observed during oxidative stress, an increase in ROS is also a messenger for increasing TNF- $\alpha{ }^{(67),(68)}$. TNF- $\alpha$ is associated with CIN severity. TNF- $\alpha$ is a proinflammatory cytokine that furtherrecruits numerous mediators associated with tissue damage. In the animal model of nephrotoxicity, TNF- $\alpha$ has a big importance in the activation of inflammatory response ${ }^{(69)}$.

Our results found that the mean level of TNF- $\alpha$ showed statistically non significant elevation in ginger group which amounted to $5.54 \%$ compared to control group $(\mathrm{P}>$ $0.05)$.

Our results demonstrated that treatment with contrast media in positive (contrast media) group showed significant increase on the mean level of TNF- $\alpha$ which amounted to $32.43 \%(\mathrm{P}<0.001)$

compared to control group ( table 4) are in agreement with ${ }^{(70),(71)}$ who reported that TNF- $\alpha$ concentration increased significantly in rats that had nephrotoxicity , increasing TNF- $\alpha$ is also observed during oxidative stress and increases and decreases in IL-1 $\beta$ and TNF- $\alpha$ were parallel among renal injury-induced groups .

Our results revealed that Treatment with ginger in therapeutic group showed non significant decrease the elevation in the mean level of cystain c, NGAL and TNF$\alpha$ which amounted to $13.41,8.51$ and $6.42 \% \quad(\mathrm{P}>0.05)$ compared to positive (contrast media) group. Meanwhile treatment with ginger in protective group showed significant decrease the elevation in the mean level of cystain c, NGAL and TNF- $\alpha$ which amounted to $41.92,14.42$ and $14.82 \% \quad(\mathrm{P}<0.05)$ compared to positive (contrast media) group. These data are in agreement with ${ }^{(72)}$ revealed that ginger has anti-inflammatory effects and suppresses the expression of proinflammatory cytokines. Also our results are in line with ${ }^{(73)}$ who reported that cystain c level remained unchanged in the 
ginger $+\quad$ Ischemia/Reperfusion Injury group compared to the Ischemia/Reperfusion Injury group.

In support to biochemical findings, our histopathological studies revealed the positive group (contrast media) showed necrosis of renal tubules, vacuolation of glomerular epithelium and congested blood vessels. These results are in consistent with (74) who revealed that tubular detachment, foamy degeneration, haemorrhagic casts and necrosis were observed in group was treated by contrast media and ${ }^{(75)}$ who reported that epithelial injury and Tubular necrosis areas were in renal outer medulla of contrast-induced nephropathy (CIN) group .

While in therapeutic group showed regenerative changes in renal tubules with less vacuolation and in protective group showed regenerative changes lead to nearly normal renal tubules and renal glomerular and these results agreed with ${ }^{(76)}$ who reported that The corrective histopathological findings after treatment with ginger extracts give an additional support that ginger mops up free radicals generation by cadmium and induces healthy state of renal cells, suggesting its role as renal protective agent .Also our results are in line with ${ }^{(77)}$ who revealed that improvement of kidney tissues were markedly ameliorated pretreatment with ginger as shown in (Fig 11)

\section{References}

1. Dugbartey $\mathbf{G} \mathbf{J}$ and Redington A N (2018): Prevention of contrast-induced nephropathy by limb ischemic preconditioning: underlying mechanisms and clinical effects American J Renal Physiology.

2. wong Y P, LI Z, Guo J, Zhang A. (2012): Pathophysiology of contrast-induced nephropathy. Int J Cardiol ., 158:186-92.
3. Maliborski A, zukowski P, Nowicki G, Boguslawska R . (2011): Contrastinduced nephropathy a review of current literature and guidelines. Med Sci Monit 17:199-204.

4. Yang JS, Peng YR, Tsai SC, Tyan YS, Lu CC, Chiu HY, Chiu YJ, Kuo SC, Tsai YF, Lin PC, Tsai FJ (2018): The molecular mechanism of contrastinduced nephropathy (CIN) and its link to in vitro studies on iodinated contrast media (CM). Biomedicine (Taipei). 8; (1):1

5. Heyman SN, Rosen S, Khamaisi $M$, Idee JM, Rosenberger C.(2010): Reactive oxygen species and the pathogenesis of radiocontrast-induced nephropathy. Invest Radiol : 45:188-195.

6. Akyol S, Ugurcu V, Altuntas A, et al (2014): Caffeic acid phenethyl ester as a protective agent against nephrotoxicity and/or oxidative kidney damage: a detailed systematic review. ScientificWorldJournal; 2014:561971.

7. Demin, G. and Yingying, $Z$. (2010): Comparative antibacterial activities of crude polysaccharides and flavonoids from Zingiber officinale and their extraction. American Journal of Tropical Medicine 5: 235-238.

8. Yiming, L., Van, H. T., Colin, C. D., and Basil, D. R. (2012): Preventive and Protective Properties of Zingiber officinale (Ginger) in Diabetes Mellitus, Diabetic Complications, and Associated Lipid and Other 
Metabolic Disorders: A Brief Review. Evidence-Based Complementary and Alternative Medicine, 2012(516870): 1-10.

9. Surh, Y.J. (2002): Food Chem Toxicol. 40, 1091-1097.

10. Morakinyo A. O, Akindele A J, Ahmed Z ( 2011) : Modulation of Antioxidant Enzymes and Inflammatory Cytokines: Possible Mechanism of Anti-diabetic Effect of Ginger Extracts. Afr. J. Biomed. ); $195-202$.

11. Tabacco.A., meiattinif., moda E., and Tarlip (1979): simplified enzymatic colormetric serum urea nitrogen determination . clin. Chem. 25:336-337.

12.Hennery R.J. Cannon D.C. and winkelm J.W. (1974): clinical chemistry : principles and technique , $2^{\text {nd }}$ ed., new york, harper and Row ; pp. 422-424.

13. Montgomery,H.A C. and dymock, J.F.(1961): the determination of nitrite in water . Analyst, 86:414 416.

14. Ohkawa, H., oishi N. and Yagi , K.(1979): Anal . Biochem., 95:351.
15. Beutler, E., duron ,O. and Kelly ,M.B.(1963): Improved method for the determination of blood glutathione .J.lab. clin.Med., 61: 882-890.

16. Nishikimi, M., Rao, N. A. and Yagi, K. (1972): The occurrence of superoxide anion in the reaction of reduced phenazine methosulfate and molecular oxygen. Biochem. Biophys. Res. Commun., 46, 849-854.

17. Levesque, R. $\quad$ (2007): Programming and Data Management for SPSS Statistics 17.0: A Guide for SPSS Statistics and SAS Users. SPSS, Chicago.

\section{YeniceriogluY,Yilmaz O,} Sarioglu S et al. (2006). Effects of $\mathrm{N}$-acetylcysteine on radio contrast nephropathy in rats. Scand J Urol Nephrol; 40: 63-69.

19. Wang YX, Jia YF, Chen KM et al. (2001). Radiographic contrast media induced nephropathy: experimental observations and the protective effect of calcium channel blockers. Br J Radiol; 74: 1103-1108.

20. Deray G, Baumelou B, Martinez F et al (1991). Renal vasoconstriction after low and high osmolar contrast agents in ischemic and nonischemic canine kidney. Clin Nephrol; 36: 93-96.

21. Toprak O, Cirit M.(2006). Risk factors for contrast-induced nephropathy. Kidney Blood Press Res; 29: 84-93.

22. Salih Inal S, Koc E, Okyay G U, Özge T. Pasaoglu, Gönül I I, Oyar E O, Pasaoglu H, Güz G (2014). Protective effect of 
adrenomedullin on contrast induced nephropathy in rats. Nefrologia;34(6):724-31.

23. Toprak O, Cirit M, Tanrisev M, Yazici C, Canoz O, Sipahioglu M , Uzum A , Ersoy $R$ and Sozmen E Y (2008). Preventive effect of nebivolol on contrast-induced nephropathy in rats .Nephrol Dial Transplant 23: 853-859.

24. Azu, O.O.; Francis, I.O.D.; Abraham, A.O.; Crescie, C.N.; Stephen, O.E. and Abayomi, O.O. (2010): Protective Agent, Kigelia Africana Fruit Extract, Against Cisplatin-Induced Kidney Oxidant Injury in SpragueDawley Rats. Asian J Pharma Clin Res. 3: 84-88.

25. Anusuya, N.; P. Durgadevi,; A. Dhinek and S. Mythily, (2013). Nephroprotective effect of ethanolic extract of garlic (Allium sativum L.) on cisplatin induced nephrotoxicity in male wistar rats.

26. Dickey, D.T.; Muldoon, L.L.; Doolittle, N.D.; Peterson, D.R. ; Kraemer D.F. and Neuwelt, E.A.(2008).Effect of Nacetylcysteine route of administration on chemoprotection against cisplatininducedtoxicity in rat models. Cancer Chemotherapy Pharmacol., 62: 235-241.

27. Azmus AD, Gottschall C, Manica A, Manica J, Duro K, Frey M, Bulcao L, Lima $C($ 2005). Effectiveness of acetylcysteine in prevention of contrast nephropathy. The Journal of invasive cardiology .;17:80-84.
28. Baker CS, Wragg A, Kumar S, De Palma R, Baker LR, Knight CJ.( 2003). A rapid protocol for the prevention of contrast-induced renal dysfunction: The rappid study. Journal of the American College of Cardiology.;41:21142118.

29. Hou J, Yan G, Liu B, Zhu B, Qiao Y, Wang D, Li R, Luo E, Tang C. (2018). The Protective Effects of Enalapril Maleate and Folic Acid Tablets against Contrast-Induced

Nephropathy in Diabetic Rats. Biomed Res Int. Feb 7;2018:4609750.

30. GongX, Duan Y, Zheng J, Wang Y, Wang G, Norgren S, and Tom K. Hei (2016) Nephroprotective Effects of NAcetylcysteine Amide against Contrast-Induced Nephropathy through Upregulating Thioredoxin-1, Inhibiting ASK1/p38MAPK Pathway, and Suppressing Oxidative Stress and Apoptosis in Rats. 8715185.

31. Yue R, Zuo C, Zeng J, Su B, Tao Y, Huang S, Zeng $R$. (2017). Atorvastatin attenuates experimental contrast-

induced acute kidney injury: a role for TLR4/MyD88 signaling pathway. Ren Fail. Nov;39(1):643-651.

32. Nasri H, Nematbakhsh $M$, Ghobadi S, Ansari R, Najmeh S Shahinfard and -kopaei M R (2013). Preventive and Curative Effects of Ginger Extract Against Histopathologic Changes of Gentamicin-Induced Tubular Toxicity in Rats. International 
journal of preventive medicine 4(3):316-21.

33. Krim M, Messaadia A, Maidi I, Aouacheri O, Saka S (2013). Protective effect of ginger against toxicity induced by chromate in rats. Ann Biol Clin; 71 (2): 16573.

34. Shimizu MH, Araujo M, Borges SM, de Tolosa EM, Seguro AC.(2004). Influence of age and vitamin $\mathrm{E}$ on post-ischemic acute renal failure.

$\operatorname{Exp}$

Gerontol;39(5):825-30.

35. Tepel $M$, van der Giet $M$, Schwarzfeld C, Laufer U, Liermann D, Zidek W.(2000). Prevention of radiographiccontrast-agent-induced reductions in renal function by acetylcysteine. N Engl J Med;343(3):180-4.

36. Aspelin P, Aubry P, Fransson SG, Strasser R, Willenbrock R, Berg KJ.(2003). Nephrotoxic effects in high-risk patients undergoing angiography. N Engl J Med;348(6):491-9.

37. Asif A, Epstein M.(2004). Prevention of radiocontrast-induced nephropathy. Am J Kidney Dis ;44:12-24.

38. Detrenis S, Meschi M, Musini S, Savazzi G.(2005). Lights and shadows on the pathogenesis of contrast-induced nephropathy: State of the art. Nephrol Dial Transplant.;20:1542-1550.

39. Wang N, R.-B. Wei, Q.-P. Li et al., (2015) "Renal protective effect of probucol in rats with contrast-induced nephropathy and its underlying mechanism," Medical Science Monitor, vol. 21, pp. 2886-2892.

40. Tasanarong A, Kongkham S, and Itharat A, (2014) "Antioxidant effect of Phyllanthus emblica extract prevents contrastinduced acute kidney injury," BMC Complementary and Alternative Medicine, vol. 14, article 138.

41. Thomas DD, Espey MG, Ridnou r LA, et al.(2004). Hypoxic inducible factor 1alpha, extracellular signal-regulated kinase, and p53 are regulated by distinct threshold concentrations of nitric oxide. Proc Natl Acad Sci U S A.;101:8894-8899.

42. Hannibal L. et al.,(2016). Nitric oxide homeostasis in neurodegenerative diseases. Curr Alzheimer Res.;13:135-149.

43. Quintavalle C, Brenca M, De MiccoF, et al. (2011). In vivo and in vitro assessment of pathways involved in contrast mediainduced renal cells apoptosis. Cell Death Dis.;2:155.

44. Aksu F, Aksu B, Unlu N, Karaca T, Ayvaz S, Erman H, Uzun H, Keles N, Bulur S \& Unlu E (2016) . Antioxidant and renoprotective effects of sphingosylphosphorylcholine on contrast-induced nephropathy in rats . Renal Failure J.

45. Karaman A, Diyarbakir B, Subasi I D, Kose D, BilginA O, Topcu A, Gundogdu C, Karakaya A D, Aktutan Z B and Alper F(2016). A novel approach to contrast-induced 
nephrotoxicity: the melatonergic agent agomelatine . Br J Radiol 2016; 89: 20150716.

46. Baykara M, Silici S, Özçelik M, Güler O, Erdoğan N, Bilgen M, (2015) In vivo nephroprotective efficacy of propolis against contrast-induced nephropathy . Diagn Interv Radiol; 21: 317-321.

47. Francisco A. P, Mara M. G. Prata M.G, Oliveira I.C M, Alves $\mathbf{N}$ T Q, R E M, Monteiro H S A , Silva J A, Vieira $P$ C, Viana D A, A B , and Havt (2014).Gingerol Fraction from Zingiber officinale Protects against Gentamicin-Induced Nephrotoxicity. Antimicrob Agents Chemother. Apr; 58(4): 1872-1878.

48. Ippoushi $\quad$ K, Azuma K, Ito H, Horie H, Higashio H.(2003). [6]-Gingerol inhibits nitric oxide synthesis in activated J774.1 mouse macrophages and prevents peroxynitrite-induced oxidation and nitration reactions. Life Sci. Nov 14;73(26):3427-37.

$\begin{array}{cc}\text { 49. Ghasemzadeh } & \text { A, Jaafar } \\ \text { HZ, Rahmat } & \text { A.(2010). }\end{array}$

Antioxidant activities, total phenolics and flavonoids content in two varieties of Malaysia young ginger (Zingiber officinale Roscoe). Molecules. Jun 14;15(6):4324-33.

50. Shanmugam KR, Ramakrishna CH, Mallikarjuna $\quad K$, Reddy KS.(2010). Protective effect of ginger against alcohol-induced renal damage and antioxidant enzymes in male albino rats. Indian J Exp Biol. Feb;48(2):1439.

51.Danwilai K , Konmun J., Sripanidkulchai B O, and Subongkot S.(2017). Antioxidant activity of ginger extract as a daily supplement in cancer patients receiving adjuvant chemotherapy: a pilot study. Cancer Manag Res. ; 9: 11-18.

52. Kato K, Sato N, Yamamoto T, Iwasaki YK, Tanaka K, Mizuno K. (2008). Valuable markers for contrast-induced nephropathy in patients undergoing cardiac catheterization. Circ J. ;72:1499_ 1505.

53. Kaseda R, Iino N, Hosojima M, et al.(2007). Megalin-mediated endocytosis of cystatin $\mathrm{C}$ in proximal tubule cells. Biochem Biophys Res Commun. ;357(4):1130-1134.

54.Zhang J Z, Kang X J, Gao Y, Zheng Y Y, Wu T T, Li L, Liu F, Yang Y N, Xiao-Mei Li X M, Ma Y T \& XieX( 2017). Efficacy of alprostadil for preventing of contrast-induced nephropathy: A meta-analysis. Scientific Reports; : 1045.

55. Wang M, Zhang L, Yue R, You G, and Zeng $R$ (2016). Significance of Cystatin $\mathrm{C}$ for Early Diagnosis of ContrastInduced Nephropathy in Patients Undergoing

Coronary 
Angiography. Med Sci Monit.; 22: 2956-2961.

56. Zhang Z, Lu B, Sheng $X$, Jin N.(2011). Cystatin $C$ in prediction of acute kidney injury: a systemic review and meta-analysis. Am J Kidney Dis. ;58:356-365.

57. Briguori C, Visconti G, Rivera NV, Focaccio A, Golia B, Giannone $\mathrm{R}$, Castaldo $\mathrm{D}$, De Micco F, Ricciardelli B, Colombo A.(2010). Cystatin C and contrast-induced acute kidney injury. Circulation.;121:2117-

2122.

58. Kuwabara T, Mori K, Mukoyama M, et al.(2009). Urinary neutrophil gelatin-aseassociated lipocalin levels reflect damage to glomeruli, proximal tubules, and distal nephrons. Kidney Int. ;75(3):285294.

59. Hvidberg V, Jacobsen C, Strong RK, Cowland JB, Moestrup SK, Borregaard N.( 2005). The endocytic receptor megalin binds the iron transporting neutrophilgelatinase-associated lipocalin with high affinity and mediates its cellular uptake. FEBS Lett. ;579(3):773-777.

60. Mishra J, Ma Q, Kelly C, Mitsnefes M, Mori K, Barasch J, Devarajan P (2006). Kidney NGAL is a novel early marker of acute injury following transplantation. Pediatr Nephrol 21:856-863.

61. Rosenthal S H, Marggraf G, Husing J, et al. (2004). Early detection of acute renal failure by serum cystatin C. Kidney Int. ;66(3):1115-1122.

62.Xu $S$ and Venge $P$ (2000) Lipocalins as biomarkers of disease. Biochim Biophys Acta 1482:298-307.

63. Charlton JR, Portilla D and Okusa MD. (2014). A basic science view of acute kidney injury biomarkers. Nephrol Dial Transplant. ;29(7):1301-1311.

64. Kafkas N, Liakos

C, Zoubouloglou F, Dagadaki O, Dragasis S, Makris K (2016). Neutrophil Gelatinase-Associated Lipocalin as an Early Marker of Contrast-Induced Nephropathy After Elective Invasive Cardiac Procedures. Clin Cardiol. Aug;39(8):464-70.

65. Cadirci E, Altunkaynak BZ, Halici Z, Odabasoglu F, Uyanik MH, Gundogdu C, et al. (2010). Alpha-lipoic acid as a potential target for the treatment of lung injury caused by cecal ligation and puncture-induced sepsis model in rats. Shock; 33: 479-84.

66. Yayla M, Halici Z, Unal B, Bayir Y, Akpinar E and Gocer F.(2014). Protective effect of Et-1 receptor antagonist bosentan on paracetamol induced acute liver toxicity in rats. Eur J Pharmacol ; 726: 87-95.

67. Zhou ZX, Wang LP, Song ZY, Lambert JC, McClain CJ, Kang YJ. (2003). A critical involvement of oxidative stress in acute alcohol-induced hepatic TNFalpha production. Am J Pathol; 163: 1137-46. 
68. Kuhad A and Chopra K.( 2009). Attenuation of diabetic nephropathy by tocotrienol: Involvement of $\mathrm{NFkB}$ signaling pathway. Life Sci; 84: 296-301.

69. Gazi S, Altun A, Erdogan O.(2006). Contrast induced nephropathy: preventive and protective effects of melatonin. $\mathbf{J}$ Pineal Res; 41: 53-7.

70. Palabiyik S S., Dincer B, Cadirci E, Cinar I, Gundogdu C, Polat B, Yayla M \&Halici $\mathbf{Z}(2017$ ). A new update for radiocontrast-induced

nephropathy aggravated with glycerol in rats: the protective potential of epigallocatechin-3gallate . renal failure $\mathrm{j}$.

71. Kunakv C S, Ugan R A , Cadirci E , Karakus E, Polat B, Un H , Halici Z, Sritemur M, Atmacah $T$ and Karaman A.(2015). Nephroprotective potential of carnitine against glycerol and contrast-induced kidney injury in rats through modulation of oxidative stress, proinflammatory cytokines, and apoptosis . BJR .

72. Shirpoor A, Hasan M, Ilkhanizadeh B, Ansari KH, Nemati S (2016). Protective Effects of Ginger (Zingiber officinale) Extract against Diabetes-Induced Heart Abnormality in Rats. Diabetes Metab J. 2016 Feb; 40(1): 46-53.

73. Ebru Uz, Omer Faruk Karatas , Emin Mete and Ali Akcay
(2009). The Effect of Dietary Ginger ( Zingiber officinals Rosc) on Renal Ischemia/Reperfusion Injury in Rat Kidneys.

74. Zhao B , Zhao O, Li J, Xing T, Wang $F$, Wang $N$ (2015). Renalase Protects against Contrast-Induced Nephropathy in Sprague-Dawley Rats. PLOS J.

75. Ari E, A E Kedrah, MD, Y Alahdab, MD, G Bulut, MD, Z Eren, MD, O Baytekin, MD, and D Odabasi, MD (2012). Antioxidant and renoprotective effects of paricalcitol on experimental contrast-induced nephropathy model. Br J Radiol. Aug; 85(1016): 1038-1043.

76. Gabr S A, Alghadir A H , (2017). Biological activities of ginger against cadmium-induced renal toxicity. Saudi Journal of Biological Sciences.

77. Lakshmi B.V.S and Sudhakar M, (2010). Protective Effect of Zingiber officinale on

Gentamicin-Induced

Nephrotoxicity in

Rats.International Journal of Pharmacology, 6: 58-62. 
Table (1): Effect of water deprivation on body weight in all studied groups.

\begin{tabular}{|c|l|c|c|}
\hline Group & & $\begin{array}{l}\text { Weight before deprivation } \\
(\mathbf{g m})\end{array}$ & $\begin{array}{l}\text { Weight after } \\
\text { deprivation (gm) }\end{array}$ \\
\hline Control & Mean \pm SD & $225.5 \pm 4.37$ & $201.8 \pm 5.87$ \\
\hline Ginger & Mean \pm SD & $194.2 \pm 16.19$ & $134.17 \pm 66.67$ \\
\hline Protective & Mean \pm SD & $205.3 \pm 15.35$ & $180.83 \pm 18.86$. \\
\hline $\begin{array}{l}\text { Positive (contrast } \\
\text { media) }\end{array}$ & Mean \pm SD & $198.16 \pm 16.54$ & 173.5 \\
\hline Therapeutic & Mean \pm SD & $200.33 \pm 9.97$ & $17.66 \pm 8.06$ \\
\hline
\end{tabular}

Table(2): Effect of ginger extract on kidney function tests in all studied groups

\begin{tabular}{|c|c|c|c|}
\hline Group & & $\begin{array}{l}\text { Blood urea } \\
\text { (mg/dl) }\end{array}$ & $\begin{array}{c}\text { Creatinine } \\
\text { (mg/dl) }\end{array}$ \\
\hline Control & Mean $\pm \mathrm{SD}$ & $71 \pm 3.82$ & $.84 \pm .047$ \\
\hline \multirow{3}{*}{ Ginger } & Mean $\pm S D$ & $72.06 \pm 3.16$ & $.82 \pm .07$ \\
\hline & $\% *$ & 1.5 & -2.39 \\
\hline & $\mathrm{P} *$ & .991 & .998 \\
\hline \multirow{5}{*}{ Protective } & Mean $\pm \mathrm{SD}$ & $72.61 \pm 3.72$ & $.86 \pm .06$ \\
\hline & $\% *$ & 2.27 & 2.38 \\
\hline & $\mathrm{P} *$ & .958 & .999 \\
\hline & $\% * *$ & -7.79 & -16.51 \\
\hline & $\mathrm{P} * *$ & .091 & .082 \\
\hline \multirow{3}{*}{$\begin{array}{c}\text { Positive } \\
\text { (contrast media) }\end{array}$} & Mean \pm SD & $78.75 \pm 1.58$ & $1.03 \pm .16$ \\
\hline & $\% *$ & 10.92 & 22.62 \\
\hline & $\mathrm{P} *$ & .019 & .047 \\
\hline \multirow{5}{*}{ Therapeutic } & Mean $\pm \mathrm{SD}$ & $76.26 \pm 4.61$ & $.927 \pm .063$ \\
\hline & $\% *$ & 7.41 & 10.36 \\
\hline & $\mathrm{P} *$ & .188 & .683 \\
\hline & $\% * *$ & -3.16 & -10 \\
\hline & $\mathrm{P} * *$ & .827 & .512 \\
\hline
\end{tabular}

$\mathrm{P} * \& \mathrm{P} * *$ in compared to control and positive group respectively, value considered significant at $\mathrm{P}<0.05$. Also, $\% * \& \% * *$ percent change in compared to control and positive (contrast media) groups respectively. 
Table (3): Effect of ginger extract on oxidant and antioxidant levels in all studied group

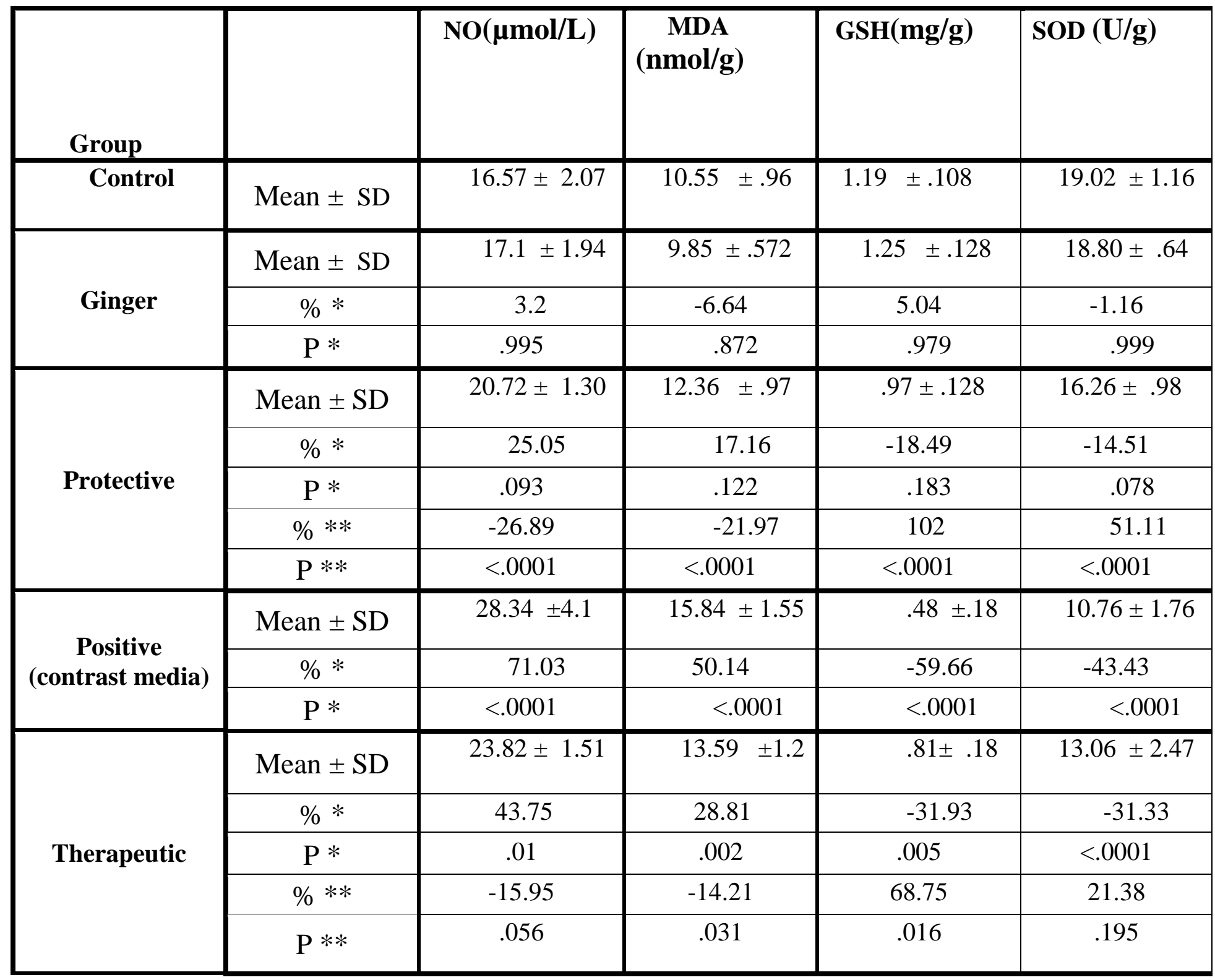


Table (4): effect of ginger extract on inflammatory markers in all studied groups

\begin{tabular}{|c|c|c|c|c|}
\hline Group & & $\begin{array}{l}\text { Cystain-C } \\
(\mathrm{ng} / \mathrm{ml})\end{array}$ & $\begin{array}{l}\text { N-GAL } \\
(\mathbf{p g} / \mathrm{ml})\end{array}$ & TNF- $\alpha(n g / l)$ \\
\hline Control & Mean \pm SD & $61.33 \pm 16.72$ & $212.43 \pm 22.25$ & $224.77 \pm 22.77$ \\
\hline \multirow{3}{*}{ Ginger } & Mean $\pm \mathrm{SD}$ & $62.83 \pm 17.92$ & $222.81 \pm 16.92$ & $237.22 \pm 30.46$ \\
\hline & $\% *$ & 2.45 & 4.88 & 5.54 \\
\hline & $\mathrm{P} *$ & .911 & .911 & .911 \\
\hline \multirow{5}{*}{ Protective } & Mean \pm SD & $72.88 \pm 15.72$ & $239.16 \pm 3.25$ & $253.55 \pm 16.81$ \\
\hline & $\% *$ & 18.83 & 12.58 & 12.8 \\
\hline & $\mathrm{P} *$ & .298 & .2 & .298 \\
\hline & $\% * *$ & -41.92 & -14.42 & -14.82 \\
\hline & $\mathrm{P} * *$ & .036 & .017 & .036 \\
\hline \multirow{3}{*}{$\begin{array}{c}\text { Positive } \\
\text { (contrast media) }\end{array}$} & Mean $\pm \mathrm{SD}$ & $125.48 \pm 53.19$ & $279.46 \pm 21.42$ & $297.66 \pm 22.03$ \\
\hline & $\% *$ & 104.59 & 31.55 & 32.43 \\
\hline & $\mathrm{P} * *$ & $<.0001$ & $<.0001$ & $<.0001$ \\
\hline \multirow{5}{*}{ Therapeutic } & Mean \pm SD & $108.65 \pm 44.99$ & $255.68 \pm 20.07$ & $278.55 \pm 13.41$ \\
\hline & $\% *$ & 77.16 & 20.36 & 23.93 \\
\hline & $\mathrm{P} *$ & .007 & .009 & .007 \\
\hline & $\% * *$ & -13.41 & -8.51 & -6.42 \\
\hline & $\mathrm{P} * *$ & .685 & .304 & .685 \\
\hline
\end{tabular}

$\mathrm{P}^{*} \& \mathrm{P} * *$ in compared to control and positive group respectively, value considered significant at $\mathrm{P}<0.05$. Also, $\% * \& \% * *$ percent change in compared to control and positive (contrast media) groups respectively. 


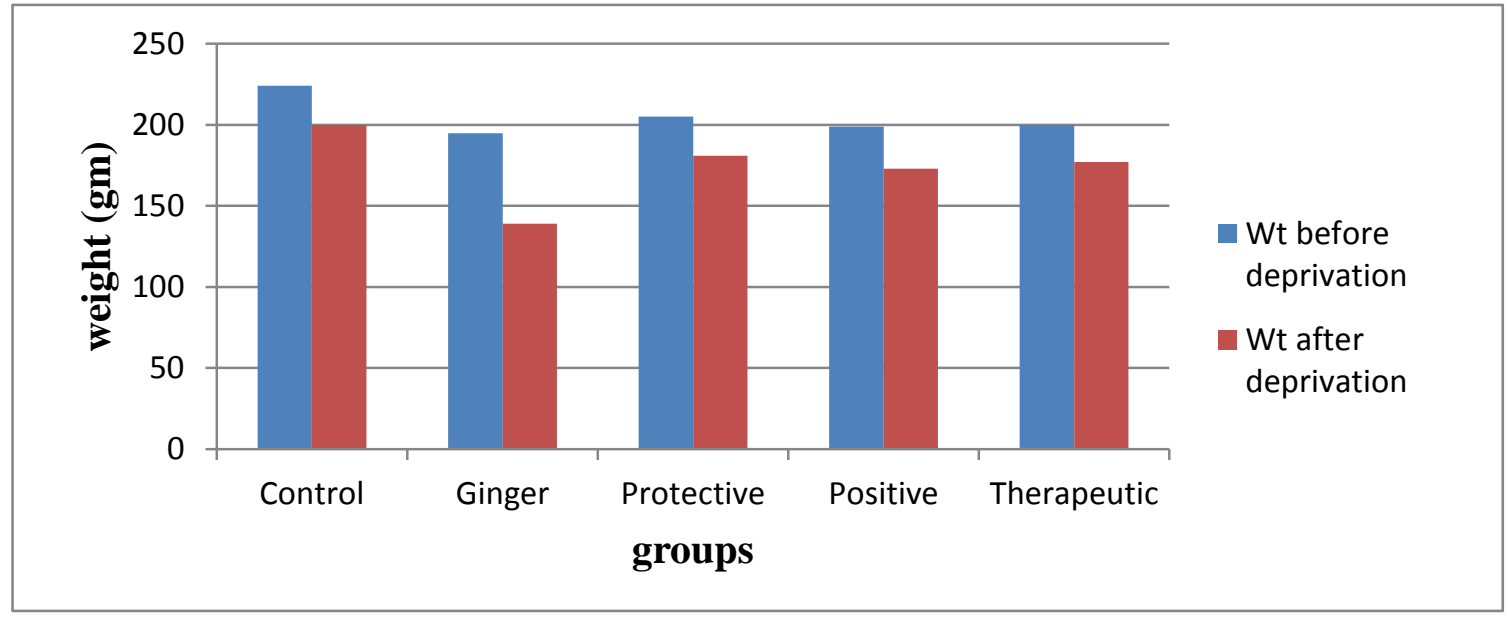

Fig1 : Mean groups of body weight in all studied groups

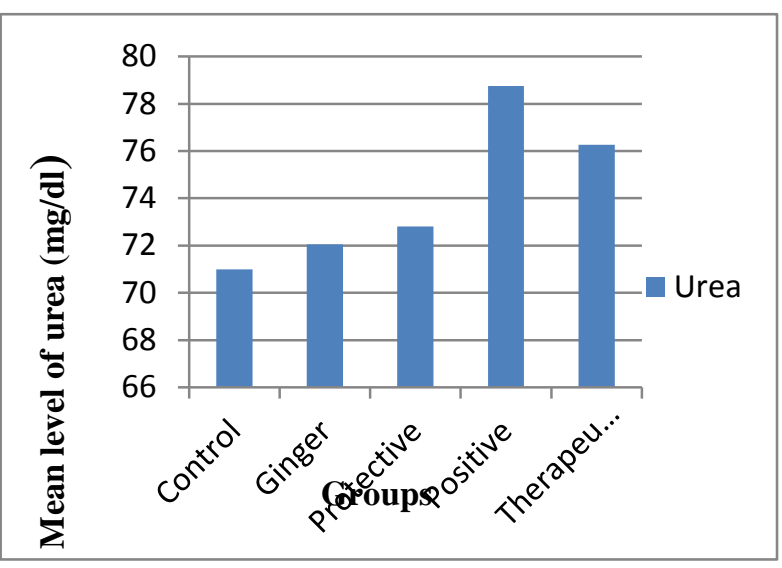

Fig2: Mean level of Urea concentration in concentration all studied groups groups

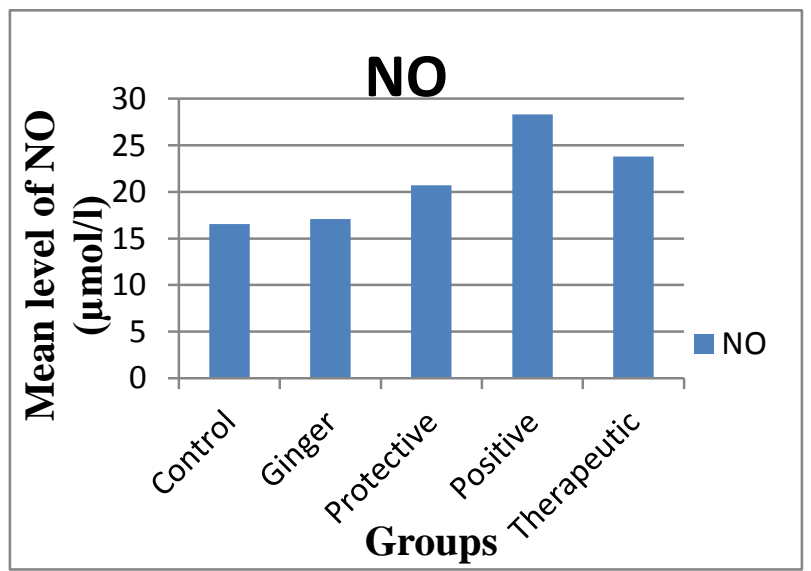

Fig4: Mean level of NO concentration in concentration groups

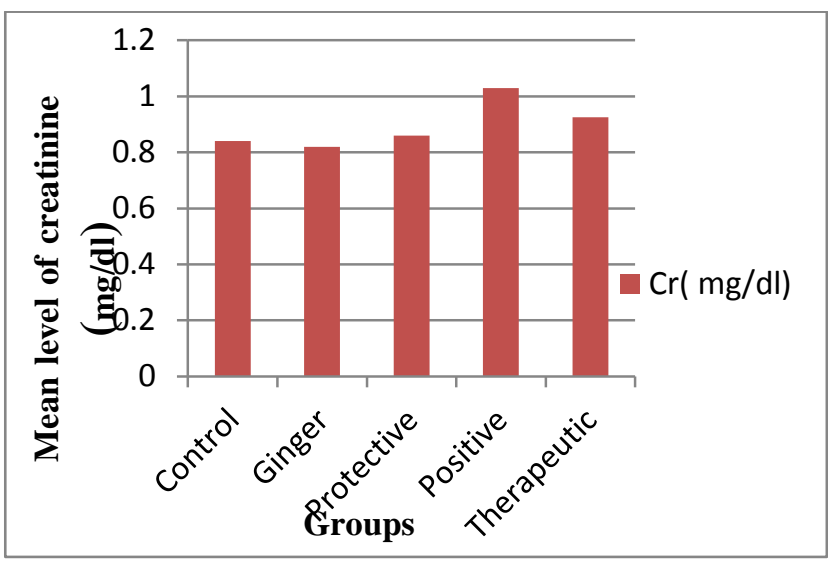

Fig3: Mean level of creatinine in all studied

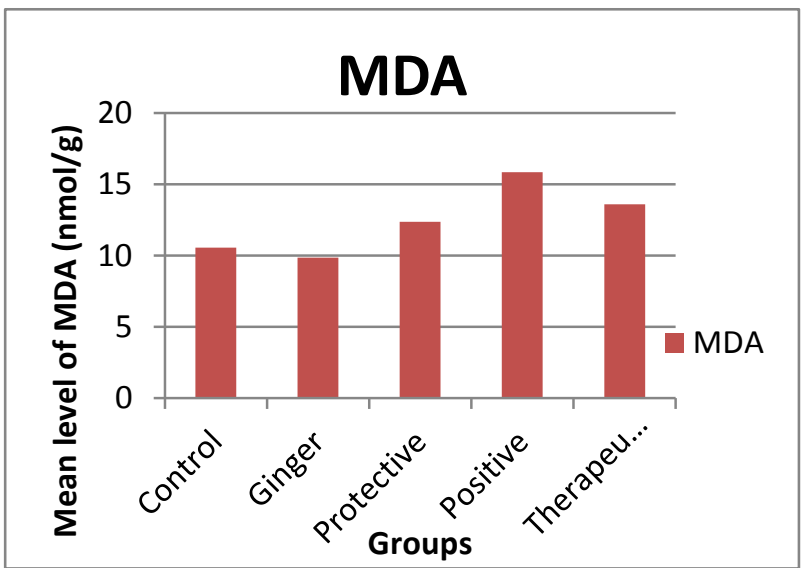

Fig5: Mean level of MDA in all studied 


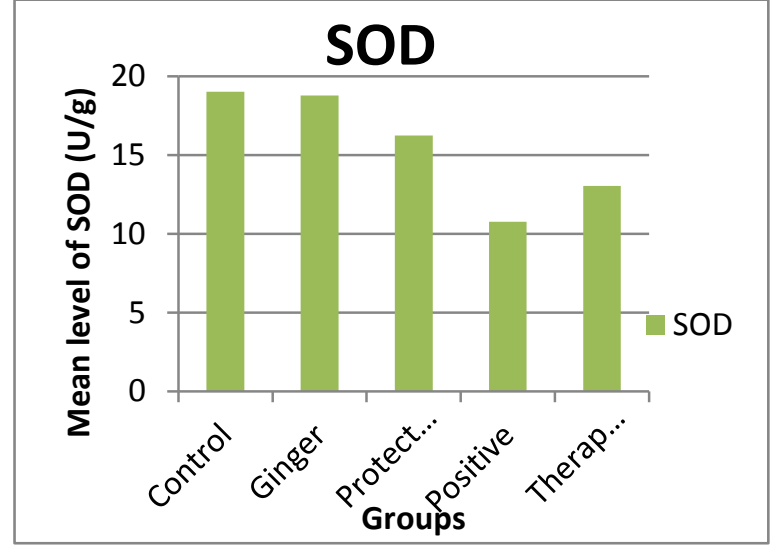

Fig6: Mean level of SOD activity in all studied groups

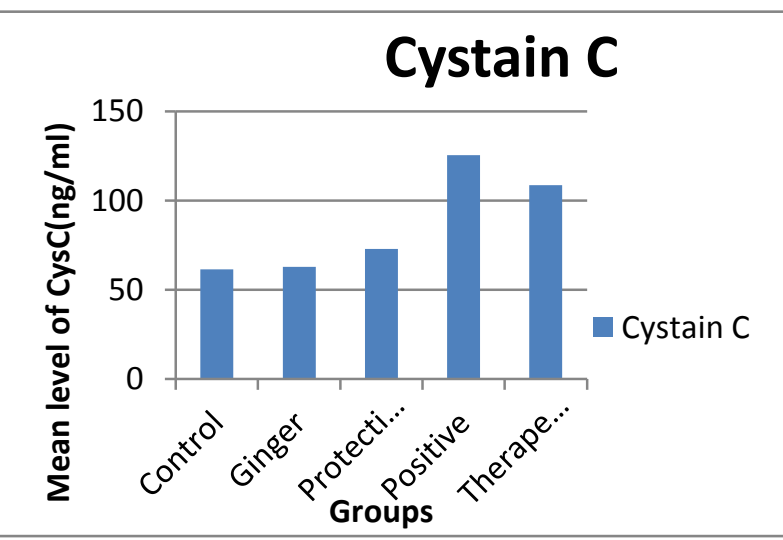

Fig8: Mean level of cystain $C$ concentration in all studied groups

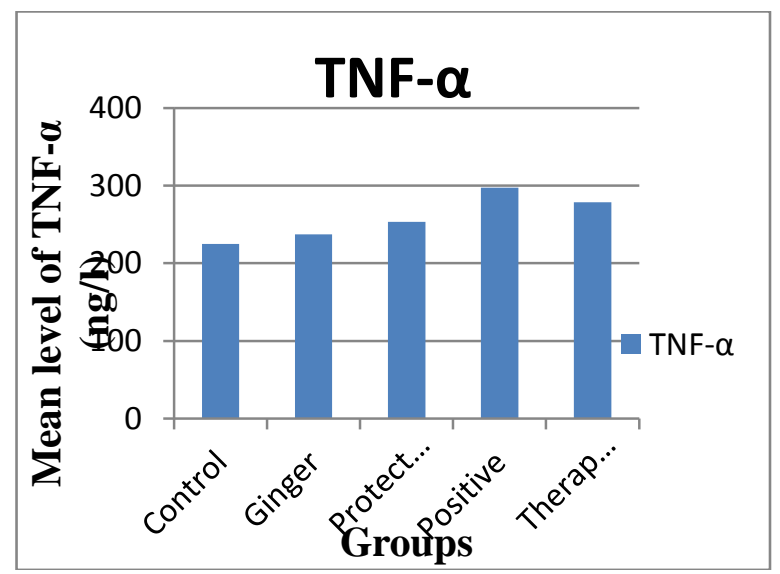

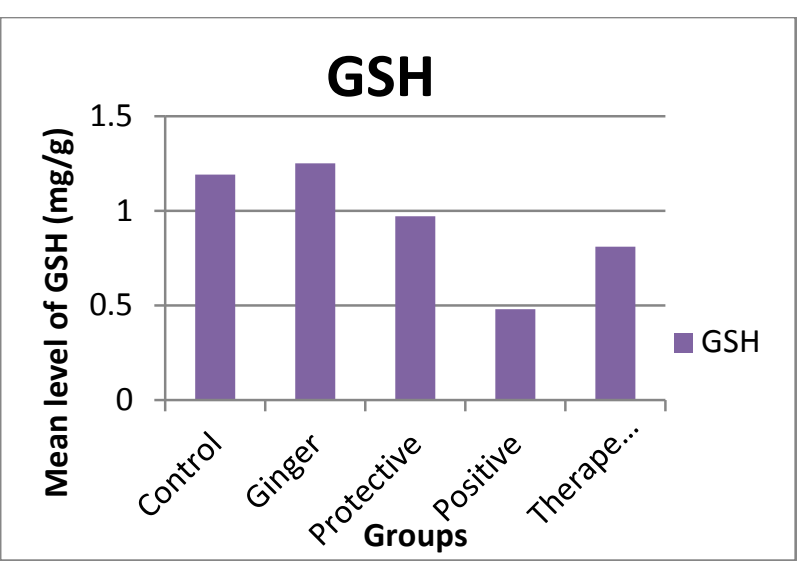

Fig7: Mean level of GSH concentration in all studied groups

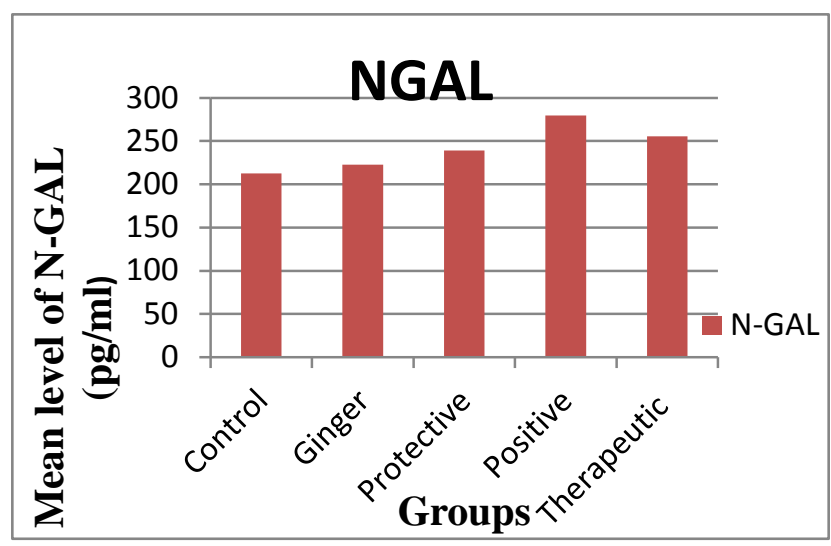

Fig9: Mean level of NGAL concentration in all studied groups

Fig10: Mean level of TNF $\alpha$ concentration in all studied groups 
(A)

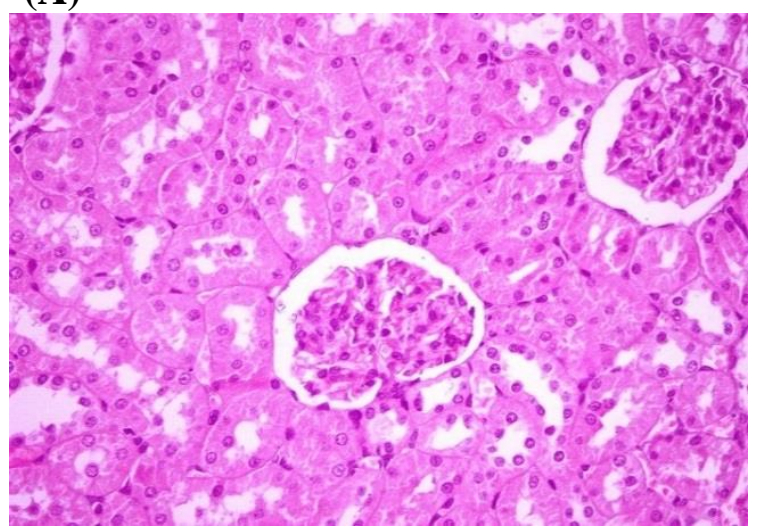

(C)

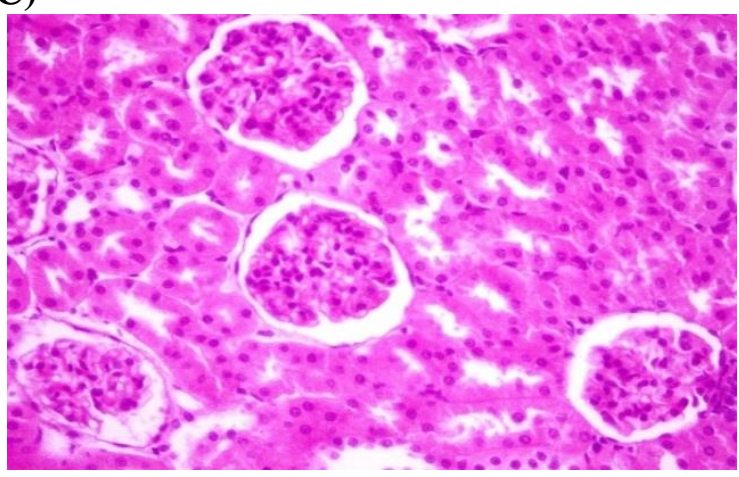

( E)

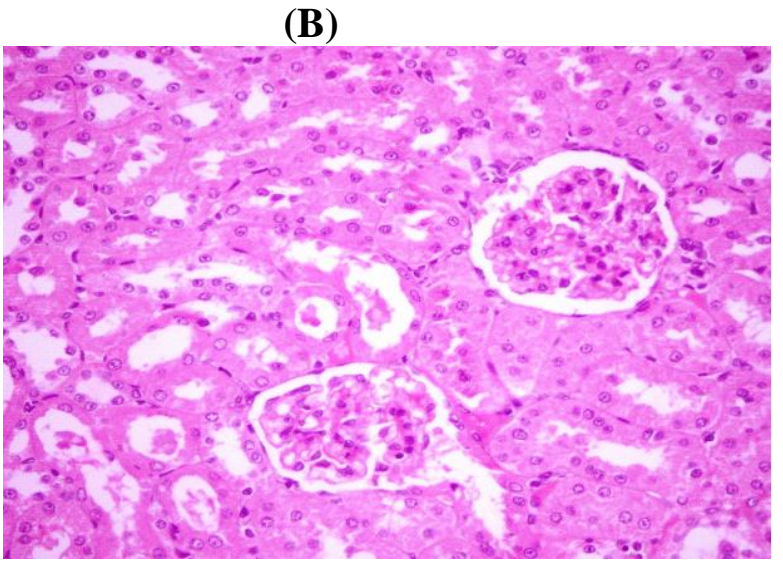

( D )

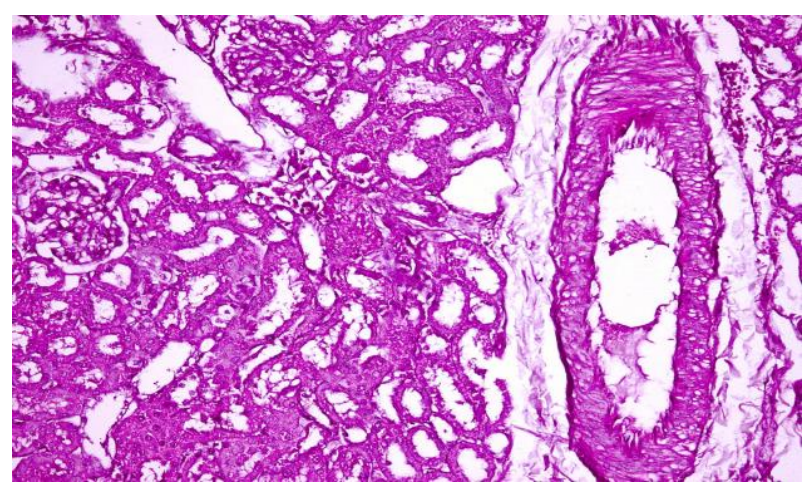

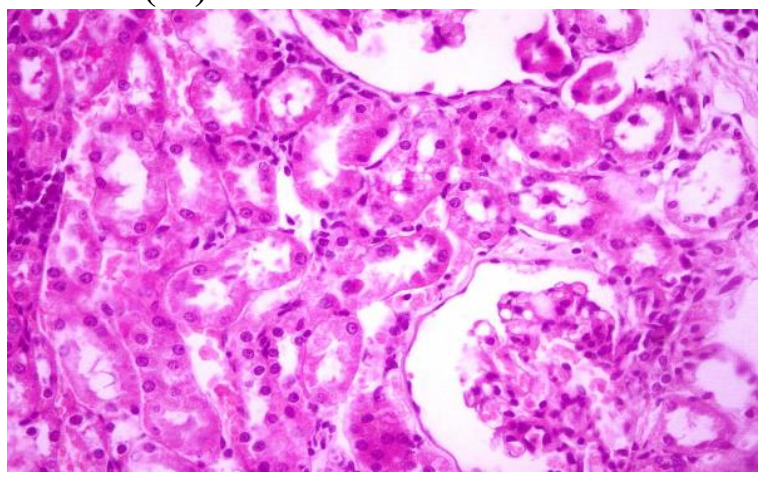

Fig11: Histological architecture of rat kidney tissue (A): normal renal tubules, and renal glomeruli $(B)$ : ginger treated group showed normal renal tubules, and renal glomeruli (C): protective group showed quite normal renal tubules, and renal glomeruli (D): positive group showed Vacuolation of glomerular epithelium and necrosis of renal tubules $(E)$ : therapeutic group showed regenerative changes in the renal tubules $(H \& E$ $\mathrm{X}$ 400). 